\title{
Effects of nutritional plans and genetic groups on performance, carcass and meat quality traits of finishing pigs ${ }^{\star *}$
}

\author{
Rogério de Carvalho VELOSO ${ }^{1}$, Márcio de Souza DUARTE ${ }^{1}$, Fabyano Fonseca e SILVA ${ }^{1}$, \\ Alysson SARAIVA ${ }^{1}$, Simone Eliza Facioni GUIMARÃES ${ }^{1}$, Mário Luiz CHIZZOTTI ${ }^{1}$, \\ Ederson Gomes CAMARGO ${ }^{1}$, Paulo Sávio LOPES ${ }^{1 \star}$
}

\begin{abstract}
We aimed to evaluate the effects of paternal genotypes (Piau, Duroc-based, and Pietrain) and nutritional plans with different digestible lysine contents (Low, Medium, and High) on performance, carcass, and meat quality traits of pigs. Pietrain and Duroc crossbred barrows and gilts were similar in performance and carcass traits and had the greatest values when compared to Piau crossbred pigs. Regarding meat quality, drip loss was greater in pork from Pietrain crossbred barrows and gilts compared to Duroc and Piau crossbred pigs. The High nutritional plan had the greatest daily digestible lysine intake value, followed by the Medium and Low nutritional plans. Most of the performance, carcass, and meat quality traits that were evaluated in barrows and gilts were not affected by the nutritional plans. In general, Duroc and Pietrain crossbred pigs had a greater performance and carcass yield when compared to Piau crossbred pigs.
\end{abstract}

Keywords: crossbreeding; digestible lysine; Duroc; Piau; Pietrain.

Practical Application: Changes in digestible lysine content did substantially change carcass and pork quality traits.

\section{Introduction}

Recently, meat quality has become a concern in the swine market due to the selection for high lean growth, which results in an overall decrease in intramuscular fat deposition and tenderness (D’Astous-Pagé et al., 2017; Liu et al., 2018; Zou et al., 2017). Among different strategies that have been used to improve quality in swine production is the use of crossbreeding of genetically improved pig breeds with non-selected local pig breeds, which is a potential alternative to improve pork quality through the increase in fat content. Increasing the fat quantity adds value to the product for consumption in natura as processed products. Several studies have identified the Piau local breed as a genetic source of meat quality traits such as higher intramuscular fat (Serão et al., 2011), and thus may be used in programs aiming to improve quality as well as resistance to disease and stress in crossbred swine (Veroneze et al., 2014). For these reasons, Piau pigs may also be successfully kept in organic farms.

However, because of the discrepancy between lean growth rate of non-selected pig breeds compared to a high growth rate of selected pig breeds, different nutritional requirements are expected for the crossbred pigs. In this context, the dietary lysine requirement is one of the main concerns, since it is the first limiting amino acid in typical swine diets that are based on corn and soybean meal and also has an intrinsic relationship with muscle growth. Consequently, animal performance and lean tissue deposition are dependent on digestible lysine dietary contents (Coble et al., 2018). Therefore, we aimed to evaluate the effects of the paternal genotypes and the nutritional plans with different digestible lysine contents on performance, carcass, and meat quality traits in crossbred pigs from growth to finish.

\section{Materials and methods}

\subsection{Genetic groups and experimental diets}

The experiment was carried out at the Pig Breeding Farm of the Universidade Federal de Viçosa, Brazil. The protocol for the current research project was approved by a Ethics Committee of the institution (Protocol no 20/2014); the study was carried out according to the provisions of the Declaration of Helsinki available at WMA Declaration of Helsinki - Ethical Principles for Medical Research Involving Human Subjects.

A total of 52 barrows averaging $25.44 \pm 3.27 \mathrm{~kg}$ of initial body weight and 50 gilts averaging $24.14 \pm 3.87 \mathrm{~kg}$ of initial body weight at 70 days of age were used, and each animal was considered as an experimental unit. We used the Piau Brazilian local breed, Duroc-based line, and Pietrain breed as sires. Thus, the barrows' genetic group was composed of 18 Piau crossbred pigs [G1 = Piau male $\mathrm{x}$ (Pietrainx Large White female)], 18 Duroc crossbred pigs $[\mathrm{G} 2=$ Duroc-based male $\mathrm{x}$ (Pietrain $\mathrm{x}$ Large White female)], and 16 Pietrain crossbred pigs [G3 = Pietrain

** Part of Rogério Veloso's doctoral thesis titled "Effects of nutritional plans and genetic groups on quantitative traits of pigs", Animal Science Graduate Program, Universidade Federal de Viçosa. 
male $\mathrm{x}$ (Pietrain $\mathrm{x}$ Large White female)]. The gilt genetic group was composed of 16 Piau crossbred pigs (G1), 18 Duroc crossbred pigs (G2), and 16 Pietrain crossbred pigs (G3).

Pigs from each genetic group were randomly assigned to one of three nutritional plans based on digestible lysine (DL) levels as follows: Low (7g DL fed from 70 to 98 days of age; $6 \mathrm{~g}$ DL fed from 99 to 134 days of age; and $5 \mathrm{~g}$ DL 135 to 156 days of age), Medium ( $9 \mathrm{~g}$ DL fed from 70 to 98 days of age; $8 \mathrm{~g}$ DL fed from 99 to 134 days of age; $7 \mathrm{~g}$ DL 135 to 156 days of age), and High (11g DL fed from 70 to 98 days of age; $10 \mathrm{gDL}$ fed from 99 to 134 days of age; and 9g DL 135 to 156 days of age). Diets were formulated based on corn and soybean meal and were supplemented with minerals, vitamins, and amino acids to meet the nutritional requirements of the animals with the exception of DL, according to Rostagno et al. (2011). The proportions of essential amino acids and DL were met according to the ideal protein concept (Rostagno et al., 2011).

\subsection{Animal performance, slaughter, carcass data collection, and muscle sampling}

The amount of feed that was provided and the leftovers were recorded daily to obtain the average daily intake (g/d) of rations and $\mathrm{DL}(\mathrm{g} / \mathrm{d})$. Additionally, to obtain the average daily gain $(\mathrm{g} / \mathrm{d})$ and feed conversion rate $(\mathrm{g} / \mathrm{g})$, pigs were weighed $(\mathrm{kg})$ at the beginning and at the end of the experimental period, which started at 70 days of age and finished at 156 days of age.

The pigs were slaughtered at 156 days of age after $16 \mathrm{~h}$ of fasting. Pre-harvest handling and slaughtering procedures was in accordance with good animal welfare practices, following the Sanitary and Industrial Inspection Regulation for Animal Origin Products (Brasil, 1997).

After the slaughter, each carcass was split into two identical longitudinal halves and chilled at $4{ }^{\circ} \mathrm{C}$ for $24 \mathrm{~h}$. Following the postmortem chill, the carcasses were weighed to obtain the cold carcass yield values. Rib fat thickness (RFT) and loin eye area (LEA) were measured in the left cold carcass, $6 \mathrm{~cm}$ from the mid-line on the last rib.

Carcass $\mathrm{pH}$ was recorded at slaughter $\left(\mathrm{pH}_{0}\right)$, at $45 \mathrm{~min}$ $\left(\mathrm{pH}_{45}\right)$ after slaughter, and after thee $24 \mathrm{~h}$ postmortem chill $\left(\mathrm{pH}_{24}\right)$ by using a pHmeter (Hanna-DIGIMED model DM-20) coupled to a penetration probe (DIGIMED, DME-CV1), which was inserted into the center of the Longissimus muscle in the left half-carcass between the 12th and 13th thoracic vertebrae.

Trimmed cuts consisted of ham with bones, picnic shoulder, loin, boston shoulder, and tenderloin. Cuts were obtained in the left half of the carcass $24 \mathrm{~h}$ after the postmortem chill, and the yield was calculated as a percentage of the left half of carcass weight.

At the end of the carcass fabrication, a boneless $12 \mathrm{~cm}$ thick Longissimus section was collected. Longissimus samples were individually vacuum packaged and frozen at $-20^{\circ} \mathrm{C}$. Each frozen Longissimus sample was standardized into two $2.54 \mathrm{~cm}$ thick steak samples (American Meat Science Association, 1995). All steaks were then vacuum packaged and kept at $-20^{\circ} \mathrm{C}$.

\subsection{Instrumental color analysis}

Instrumental color analysis was performed at the beginning of the carcass fabrication after the $24 \mathrm{~h}$ postmortem chill. Color measurements were taken of the Longissimus muscle at the 10th rib after $30 \mathrm{~min}$ of blooming. A total of three readings of $L^{*}, a^{*}$, and $b^{*}$ values were obtained for each carcass. Color coordinates $\left(L^{*}, a^{*}\right.$, and $\left.b^{*}\right)$ were recorded with a digital Minolta CR300 chromometer (Minolta Co., Osaka, Japan). Coordinate $a^{\star}$ ranged from red $\left(+a^{*}\right)$ to green $\left(-a^{*}\right)$ and coordinate $b^{*}$ from yellow $\left(+b^{\star}\right)$ to blue $\left(-b^{\star}\right)$ (Hunterlab, 1996).

\subsection{Drip loss}

Drip loss was determined according to the bag method described by Honikel (1985). Briefly, meat samples were collected $24 \mathrm{~h}$ after postmortem from the 14th rib and were trimmed of visible fat and connective tissue. Then, meat samples were divided into two slices weighing approximately $120 \mathrm{~g}$. Each slice was then hung from a hook under a lid in an airtight container and kept at $4{ }^{\circ} \mathrm{C}$ for $24 \mathrm{~h}$. Following the $48 \mathrm{~h}$ chill, meat samples were weighed and the weight difference was divided by the initial sample weight.

\subsection{Cooking loss}

Cooking loss was evaluated for the meat samples that were also used for the Warner-Bratzler shear force (WBSF) measurement. Cooking loss of each sample was recorded after the steaks were oven-broiled. Total cooking loss was calculated as the difference between the weight of the steaks before and after oven-broiling.

\subsection{Warner-Bratzler shear force measurement}

For the WBSF evaluation, steaks were thawed at $4{ }^{\circ} \mathrm{C}$ for $24 \mathrm{~h}$ and oven-broiled in an electric oven (Layr, LuxoInox) that was preheated to $150^{\circ} \mathrm{C}$. Internal steak temperatures were monitored by using 20 -gauge copper-constantan thermocouples (Omega Engineering, Stamford, CT) that were placed in the approximate geometric center of each steak and attached to a digital monitor. When the internal steak temperature reached $35^{\circ} \mathrm{C}$, the steak was turned over and allowed to reach an internal temperature of $70{ }^{\circ} \mathrm{C}$ before removal from the oven. Cooked WBSF steaks were cooled for $24 \mathrm{~h}$ at $4^{\circ} \mathrm{C}$ (American Meat Science Association, 1995). Eight round cores (1.27 cm diameter) were removed from each steak parallel to the long axis of the muscle fibers (American Meat Science Association, 1995). Each core was sheared once through the center, perpendicular to the fiber direction by a Warner-Bratzler shear machine (G-R Manufacturing Company, Manhattan, KS, USA).

\subsection{Intramuscular fat content}

Powdered lyophilizated meat samples were analyzed for moisture by the Method 934.01 (Association of Official Analitical Chemists, 1990) and ether extract (EE) by the Method Am 5-04 (American Oil Chemists' Society, 2009) to determine the intramuscular fat content. 


\subsection{Statistical analysis}

Statistical analyses were individually performed for each sex. Variables of animal performance and carcass traits (with the exception of LEA and RFT) were analyzed through the following model (Equation 1):

$y_{i j k}=m+G_{i}+N_{j}+G x N_{i j}+e_{i j k}$

where:

$G_{i}$ : ith level of the fixed effect of genetic group;

$N_{j}$ : jth level of the fixed effect of nutritional plan;

$e_{i j k}$ : random error associated with $y_{i j k}$.

The following model was used for LEA, RFT, and meat quality traits (Equation 2):

$y_{i j k}=m+G_{i}+N_{j}+G x N_{i j}+b\left(W_{i j k}-\bar{W}_{i}\right)+e_{i j k}$

where:

$G_{i}$ : ith level of the fixed effect of genetic group;

$N_{j}:$ jth level of the fixed effect of nutritional plan;

$W_{i j k}$ : slaughter weight that was used as a covariate within the genetic group;

$e_{i j k}$ : random error associated with $y_{i j k}$.

All analyses were performed using the proc Mixed procedure of SAS 9.4 (Statistical Analysis System Institute, Inc., Cary, NC, USA). Means were compared by Tukey's test and differences were considered at $P \leq 0.05$.

\section{Results}

\subsection{Barrows}

No interaction was observed between genetic group and nutritional plan for any of the performance, carcass, and meat quality variables that were evaluated in barrows $(P>0.05)$.
Final body weight (BWf) differed among genetic groups $(P=0.0001)$, where Pietrain and Duroc crossbred barrows had the greatest BWf while Piau crossbred barrows had the smallest values of BWf (Table 1). Similarly, the average daily gain (ADG) was affected by genetic group $(P=0.0001)$ where Pietrain and Duroc crossbred barrows had similar values of ADG, but their values were higher than the values observed for Piau crossbred barrows (Table 1). Consequently, feed conversion rate (FCR) was also affected by genetic group $(P=0.0001)$, where Piau crossbred barrows showed the greatest FCR values when compared to Pietrain and Duroc crossbreeds (Table 1).

As expected, the daily digestible lysine intake (DLI) differed among nutritional plan groups $(P=0.0001)$; barrows within the High nutritional plan group had the greatest value of DLI, followed by the Medium and Low nutritional plan groups (Table 1). These results demonstrate the effectiveness of the nutritional plans that were applied in the current experiment. Despite the difference in DLI among the nutritional plan groups, no effects of nutritional plans were observed for $\operatorname{BWf}(P=0.18)$, $\operatorname{ADI}(P=0.84), \operatorname{ADG}(P=0.10)$, and FCR $(P=0.09)$.

No differences were observed among genetic groups for cold carcass yield (CCY; $P=0.35$; Table 1 ). Regarding LEA, Pietrain crossbred barrows had the greatest LEA $(P<0.01)$, followed by Duroc and Piau crossbred barrows, which in turn had the smallest LEA value among the genetic groups (Table 1). On the other hand, Piau crossbred barrows had the greatest value of RFT $(P<0.01)$ when compared to Pietrain and Duroc crossbred barrows, which did not differ from each other.

Regarding trimmed cut yields, the ham and loin yields were lower in Piau crossbreeds compared to Duroc and Pietrain crossbred barrows, which did not differ from each other $(P=0.0001$; Table 1$)$. The yield of the picnic shoulder $(P=0.0001)$ and boston shoulder $(P=0.0001)$ also differed among genetic groups, where the greatest value was observed for Pietrain, followed by Duroc and Piau crossbred barrows. For the tenderloin yield, the smallest value was also observed in

Table 1. Effect of genetic group and nutritional plan of digestible lysine on performance and carcass traits of barrows.

\begin{tabular}{|c|c|c|c|c|c|c|c|c|c|c|}
\hline \multirow{2}{*}{ Item } & \multicolumn{3}{|c|}{ Genetic group } & \multirow{2}{*}{$\frac{\mathrm{CV}}{(\%)}$} & \multirow{2}{*}{ P-value } & \multicolumn{3}{|c|}{ Nutritional plan } & \multirow{2}{*}{$\frac{\mathrm{CV}}{\mathrm{( \% )}}$} & \multirow{2}{*}{ P-value } \\
\hline & G1 & G2 & G3 & & & Low & Medium & High & & \\
\hline Initial body weight (kg) & 24.52 & 26.06 & 25.65 & 12.86 & 0.39 & 24.64 & 26.24 & 25.35 & 12.84 & 0.37 \\
\hline Final body weight $(\mathrm{kg})$ & $90.86^{\mathrm{b}}$ & $108.03^{\mathrm{a}}$ & $104.28^{\mathrm{a}}$ & 9.98 & 0.0001 & 97.43 & 102.91 & 102.83 & 12.04 & 0.18 \\
\hline Average daily gain (g/d) & $781^{\mathrm{b}}$ & $971^{\mathrm{a}}$ & $930^{\mathrm{a}}$ & 10.14 & 0.0001 & 858 & 905 & 919 & 13.27 & 0.10 \\
\hline Average daily intake(g/d) & 2527 & 2607 & 2455 & 10.06 & 0.23 & 2503 & 2555 & 2531 & 10.33 & 0.84 \\
\hline Feed conversion rate(g/g) & $3.25^{\mathrm{b}}$ & $2.68^{\mathrm{a}}$ & $2.64^{\mathrm{a}}$ & 7.61 & 0.0001 & 2.93 & 2.86 & 2.77 & 12.09 & 0.09 \\
\hline Digestible lysine intake(g/d) & 21.82 & 22.09 & 21.19 & 24.88 & 0.57 & $15.91^{\mathrm{c}}$ & $22.15^{\mathrm{b}}$ & $27.05^{\mathrm{a}}$ & 11.85 & 0.0001 \\
\hline Cold carcass yield (\%) & 78.90 & 77.84 & 79.01 & 3.19 & 0.35 & 77.94 & 79.39 & 78.41 & 3.10 & 0.23 \\
\hline Loin eye area $\left(\mathrm{cm}^{2}\right)$ & $25.37^{\mathrm{c}}$ & $41.76^{\mathrm{b}}$ & $44.51^{\mathrm{a}}$ & 15.55 & 0.0002 & $33.86^{c}$ & $40.01^{\mathrm{a}}$ & $37.77^{\mathrm{b}}$ & 26.35 & 0.003 \\
\hline Rib fat thickness (mm) & $27.02^{\mathrm{a}}$ & $15.88^{\mathrm{b}}$ & $14.35^{\mathrm{b}}$ & 20.74 & 0.003 & 19.01 & 19.27 & 18.96 & 36.75 & 0.97 \\
\hline $\operatorname{Ham}(\%)$ & $22.46^{\mathrm{b}}$ & $26.28^{\mathrm{a}}$ & $26.87^{a}$ & 5.46 & 0.0001 & 25.24 & 25.14 & 25.23 & 9.48 & 0.97 \\
\hline Picnic shoulder (\%) & $14.04^{\mathrm{c}}$ & $15.35^{\mathrm{b}}$ & $16.23^{\mathrm{a}}$ & 7.01 & 0.0001 & 15.04 & 15.18 & 15.40 & 9.18 & 0.61 \\
\hline Tenderloin (\%) & $0.89^{\mathrm{b}}$ & $0.98^{\mathrm{ab}}$ & $1.05^{\mathrm{a}}$ & 15.02 & 0.02 & 0.96 & 0.99 & 0.97 & 16.34 & 0.79 \\
\hline Boston shoulder (\%) & $1.12^{\mathrm{c}}$ & $1.31^{\mathrm{b}}$ & $1.46^{\mathrm{a}}$ & 9.86 & 0.0001 & 1.29 & 1.28 & 1.31 & 14.53 & 0.76 \\
\hline Loin (\%) & $3.65^{\mathrm{b}}$ & $5.32^{\mathrm{a}}$ & $5.52^{\mathrm{a}}$ & 9.44 & 0.0001 & $4.61^{\mathrm{b}}$ & $4.89^{a}$ & $5.00^{\mathrm{a}}$ & 19.39 & 0.04 \\
\hline
\end{tabular}

CV: Coefficient of variation; G1 = Piau crossbreds; G2 = Duroc crossbreds; G3 = Pietrain crossbreds. Means with different letters differ at P $\leq 0.05$ by Tukey`s test. 
Piau compared to Pietrain crossbred barrows $(P=0.02)$, while no differences were observed for Duroc and Pietrain crossbreed genetic groups.

With regards to nutritional plans, barrows that were fed diets with the Medium nutritional plan had a greater LEA, followed by those that were fed High and Low nutritional plans, respectively $(P=0.003$; Table 1$)$. An effect of nutritional plan was also observed for loin yield $(P=0.04)$, where barrows that were fed the Low plan had the smallest loin yield value when compared to barrows that were fed Medium and High nutritional plans. The remaining carcass traits and trimmed cut yields that were evaluated were not affected by the nutritional plan $(P>0.05)$.

No differences were observed for carcass initial $\mathrm{pH}$, which was measured immediately after slaughter $\left(\mathrm{pH}_{0} P=0.65\right)$, for $\mathrm{pH}$ measured at $45 \mathrm{~min}$ postmortem $\left(\mathrm{pH}_{45} ; P=0.14\right)$, or for final $\mathrm{pH}$ measured at $24 \mathrm{~h}$ postmortem $\left(\mathrm{pH}_{24} ; P=0.64\right)$ among genetic groups (Table 2). However, different values of drip loss were observed for pork from different genetic groups $(P=0.02)$, where barrows from the Piau crossbreed group had the smallest value for this variable when compared to Pietrain crossbred barrows.
Similar values of $L^{*}(P=0.61), a^{*}(P=0.38)$, and $b^{*}(P=0.91)$ were also observed among genetic groups (Table 2). Similarly, no differences in cooking loss (CL; $P=0.64)$, Warner-Bratzler shear force (WBSF; $P=0.75$ ), and ether extract (EE; $P=0.54$ ) were observed among genetic groups (Table 2).

Although the nutritional plan affected the carcass quality traits of barrows, it did not affect any of the meat quality variables that were evaluated in this study $(P>0.05)$.

\subsection{Gilts}

No interaction was observed between genetic groups and nutritional plans for any of the evaluated performance, carcass, and meat quality variables in gilts $(P>0.05)$.

The initial body weight (BWi) differed among the genetic groups ( $P=0.0001$; Table 3 ), where Durocs had the highest value of BWi followed by Pietrain and Piau crossbred gilts, respectively. Similar results were observed for BWf $(P=0.0001)$ and ADG $(P=0.0001)$ where Duroc crossbred gilts had the greatest value of BWf and ADG followed by Pietrain and Piau crossbred gilts, respectively (Table 3 ).

Table 2. Effect of genetic group and nutritional plan of digestible lysine on meat quality traits of barrows.

\begin{tabular}{|c|c|c|c|c|c|c|c|c|c|c|}
\hline \multirow{2}{*}{ Item } & \multicolumn{3}{|c|}{ Genetic group } & \multirow{2}{*}{$\frac{C V}{(\%)}$} & \multirow{2}{*}{ P-value } & \multicolumn{3}{|c|}{ Nutritional plan } & \multirow{2}{*}{$\frac{C V}{(\%)}$} & \multirow{2}{*}{ P-value } \\
\hline & G1 & $\mathrm{G} 2$ & G3 & & & Low & Medium & High & & \\
\hline $\mathrm{pH}_{0}$ & 6.43 & 6.35 & 6.41 & 4.44 & 0.65 & 6.42 & 6.28 & 6.48 & 4.30 & 0.13 \\
\hline $\mathrm{pH}_{45}$ & 6.34 & 6.25 & 6.11 & 5.05 & 0.14 & 6.24 & 6.23 & 6.24 & 5.56 & 0.99 \\
\hline $\mathrm{pH}_{24}$ & 6.05 & 6.08 & 6.12 & 5.63 & 0.64 & 6.03 & 6.19 & 6.03 & 5.54 & 0.32 \\
\hline Drip loss (\%) & $7.77^{\mathrm{b}}$ & $9.61^{\mathrm{ab}}$ & $11.14^{\mathrm{a}}$ & 29.29 & 0.02 & 10.42 & 9.30 & 8.80 & 30.05 & 0.22 \\
\hline$L^{*}$ & 59.87 & 61.54 & 60.70 & 5.07 & 0.61 & 61.96 & 60.28 & 59.88 & 4.75 & 0.11 \\
\hline$b^{*}$ & 15.24 & 15.53 & 15.50 & 7.34 & 0.91 & 15.33 & 15.52 & 15.42 & 7.35 & 0.89 \\
\hline Cooking loss (\%) & 20.39 & 21.40 & 21.86 & 22.15 & 0.64 & 21.00 & 20.64 & 22.01 & 22.19 & 0.69 \\
\hline Shear-force (kgf) & 2.97 & 2.92 & 2.88 & 17.53 & 0.75 & 2.86 & 2.86 & 3.04 & 17.25 & 0.53 \\
\hline Ether extract (\%) & 2.20 & 2.46 & 2.32 & 19.84 & 0.54 & 2.44 & 2.19 & 2.35 & 20.23 & 0.30 \\
\hline
\end{tabular}

CV: Coefficient of variation; G1 = Piau crossbreds; G2 = Duroc crossbreds; G3 = Pietrain crossbreds. Means with different letters differ at P $\leq 0.05$ by Tukey`s test.

Table 3. Effect of genetic group and nutritional plan of digestible lysine on performance and carcass traits of gilts.

\begin{tabular}{|c|c|c|c|c|c|c|c|c|c|c|}
\hline \multirow{2}{*}{ Item } & \multicolumn{3}{|c|}{ Genetic group } & \multirow{2}{*}{$\begin{array}{l}\mathrm{CV} \\
(\%)\end{array}$} & \multirow{2}{*}{ P-value } & \multicolumn{3}{|c|}{ Nutritional plan } & \multirow{2}{*}{$\begin{array}{l}\mathrm{CV} \\
(\%)\end{array}$} & \multirow{2}{*}{ P-value } \\
\hline & G1 & G2 & G3 & & & Low & Medium & High & & \\
\hline Initial body weight (kg) & $21.68^{c}$ & $26.46^{\mathrm{a}}$ & $24.10^{\mathrm{b}}$ & 14.04 & 0.001 & 24.62 & 24.38 & 23.24 & 16.16 & 0.47 \\
\hline Final body weight (kg) & $77.93^{c}$ & $107.08^{\mathrm{a}}$ & $91.88^{\mathrm{b}}$ & 11.38 & 0.0001 & 91.88 & 92.88 & 92.13 & 17.51 & 0.96 \\
\hline Average daily gain (g/d) & $659^{c}$ & $947^{a}$ & $814^{\mathrm{b}}$ & 13.39 & 0.0001 & 793 & 813 & 813 & 20.12 & 0.82 \\
\hline Average daily intake(g/d) & $2110^{\mathrm{b}}$ & $2498^{\mathrm{a}}$ & $2180^{\mathrm{b}}$ & 11.22 & 0.0002 & 2282 & 2244 & 2262 & 13.68 & 0.73 \\
\hline Feed conversion rate $(\mathrm{g} / \mathrm{g})$ & $3.25^{\mathrm{a}}$ & $2.64^{\mathrm{b}}$ & $2.68^{\mathrm{b}}$ & 9.26 & 0.0001 & 2.93 & 2.78 & 2.86 & 13.32 & 0.25 \\
\hline Digestible lysine intake(g/d) & $17.95^{\mathrm{b}}$ & $20.88^{\mathrm{a}}$ & $18.17^{\mathrm{b}}$ & 25.21 & 0.003 & $14.28^{c}$ & $18.90^{\mathrm{b}}$ & $23.82^{\mathrm{a}}$ & 15.15 & 0.0001 \\
\hline Cold carcass yield (\%) & 76.57 & 77.62 & 78.10 & 2.48 & 0.08 & 76.66 & 77.91 & 77.72 & 2.53 & 0.13 \\
\hline Loin eye area $\left(\mathrm{cm}^{2}\right)$ & $25.82^{\mathrm{b}}$ & $44.84^{\mathrm{a}}$ & $43.63^{\mathrm{a}}$ & 11.85 & 0.0001 & 36.93 & 38.39 & 38.97 & 25.82 & 0.40 \\
\hline Rib fat thickness (mm) & $20.37^{a}$ & $14.24^{\mathrm{b}}$ & $10.50^{c}$ & 26.26 & 0.0001 & 14.93 & 15.33 & 14.85 & 37.94 & 0.94 \\
\hline $\operatorname{Ham}(\%)$ & $23.48^{\mathrm{b}}$ & $26.33^{\mathrm{a}}$ & $27.40^{\mathrm{a}}$ & 3.87 & 0.0001 & 25.66 & 25.79 & 25.75 & 7.52 & 0.93 \\
\hline Picnic shoulder (\%) & 14.80 & 15.22 & 15.57 & 6.25 & 0.09 & 15.22 & 15.13 & 15.24 & 6.61 & 0.94 \\
\hline Tenderloin (\%) & $0.94^{\mathrm{b}}$ & $1.04^{\mathrm{a}}$ & $1.07^{\mathrm{a}}$ & 12.57 & 0.03 & 1.02 & 1.02 & 1.01 & 13.57 & 0.96 \\
\hline Boston shoulder (\%) & $1.26^{\mathrm{b}}$ & $1.34^{\mathrm{b}}$ & $1.52^{\mathrm{a}}$ & 12.29 & 0.0003 & 1.34 & 1.37 & 1.41 & 14.55 & 0.53 \\
\hline Loin $(\%)$ & $4.54^{\mathrm{b}}$ & $5.62^{\mathrm{a}}$ & $6.02^{\mathrm{a}}$ & 12.38 & 0.0001 & 5.25 & 5.42 & 5.51 & 16.99 & 0.56 \\
\hline
\end{tabular}

CV: Coefficient of variation; G1 = Piau crossbreds; G2 = Duroc crossbreds; G3 = Pietrain crossbreds; Means with different letters differ at P $\leq 0.05$ by Tukey`s test. 
Table 4. Effect of genetic group and nutritional plan of digestible lysine on meat quality traits of gilts.

\begin{tabular}{|c|c|c|c|c|c|c|c|c|c|c|}
\hline \multirow{2}{*}{ Item } & \multicolumn{3}{|c|}{ Genetic group } & \multirow{2}{*}{$\frac{\text { CV }}{(\%)}$} & \multirow{2}{*}{ P-value } & \multicolumn{3}{|c|}{ Nutritional plan } & \multirow{2}{*}{$\frac{\mathrm{CV}}{\mathrm{( \% )}}$} & \multirow{2}{*}{ P-value } \\
\hline & G1 & G2 & G3 & & & Low & Medium & High & & \\
\hline $\mathrm{pH}_{0}$ & 6.41 & 6.28 & 6.36 & 5.06 & 0.59 & 6.26 & 6.34 & 6.45 & 4.88 & 0.25 \\
\hline $\mathrm{pH}_{45}$ & 6.31 & 6.27 & 6.14 & 4.95 & 0.22 & 6.21 & 6.25 & 6.25 & 4.96 & 0.55 \\
\hline $\mathrm{pH}_{24}$ & 6.04 & 6.16 & 6.11 & 5.43 & 0.79 & 6.02 & 6.00 & 6.29 & 5.35 & 0.36 \\
\hline Drip loss (\%) & $6.85^{\mathrm{b}}$ & $7.37^{\mathrm{b}}$ & $10.24^{\mathrm{a}}$ & 34.04 & 0.01 & 8.07 & 8.16 & 7.60 & 36.27 & 0.31 \\
\hline$L^{*}$ & 59.76 & 59.91 & 59.46 & 4.59 & 0.75 & 60.33 & 59.65 & 59.16 & 4.66 & 0.25 \\
\hline$a^{*}$ & 6.22 & 7.25 & 6.58 & 19.05 & 0.71 & 7.24 & 6.02 & 6.78 & 18.36 & 0.08 \\
\hline $\mathrm{b}^{*}$ & 14.97 & 15.62 & 14.93 & 7.01 & 0.74 & 15.28 & 15.14 & 15.10 & 6.97 & 0.29 \\
\hline Cooking loss (\%) & 20.00 & 21.82 & 22.12 & 13.08 & 0.33 & 22.13 & 20.47 & 21.34 & 13.80 & 0.72 \\
\hline Shear-force (kgf) & 3.55 & 3.16 & 3.37 & 22.91 & 0.75 & 3.18 & 3.25 & 3.65 & 22.23 & 0.18 \\
\hline Ether extract (\%) & 2.35 & 2.23 & 1.94 & 25.59 & 0.49 & $2.53^{\mathrm{a}}$ & $2.01^{\mathrm{ab}}$ & $1.97^{\mathrm{b}}$ & 22.81 & 0.01 \\
\hline
\end{tabular}

CV: Coefficient of variation; G1 = Piau crossbreds; G2 = Duroc crossbreds; G3 = Pietrain crossbreds. Means with different letters differ at P $\leq 0.05$ by Tukey`s test.

The ADI $(P<0.01)$, and consequently the intake of DL $(P=0.0002)$, were both affected by genetic group; Piau and Pietrain crossbred gilts did not differ from each other, but they were both lower than Duroc crossbred gilts (Table 3). Feed conversion rate was affected by genetic groups $(P=0.0001)$, where Piau had the greatest value of FCR compared to Pietrain and Duroc crossbred gilts (Table 3).

There was no effect of nutritional plan on any of the performance and carcass variables that were evaluated in gilts $(P>0.05$; Table 3$)$, except for intake of DL which differed among nutritional plans $(P=0.0001)$; this demonstrates the effectiveness of dietary treatments for the gilts groups (Table 3 ).

The LEA that was observed in Piau was lower than the LEA that was observed in Pietrain and Duroc crossbred gilts $(P=0.0001)$. On the other hand, the greatest value of RFT was observed in Piau carcasses, followed by Duroc and Pietrain crossbred gilts, respectively $(P=0.0001$; Table 3$)$.

Piau crossbred gilts had the lowest ham $(P=0.0001)$, tenderloin $(P=0.03)$, and loin $(P=0.0001)$ values compared to the remaining breeds (Table 3 ). The greatest value of boston shoulder was observed in Pietrain when compared to Duroc and Piau crossbred gilts $(P=0.0003)$. Yields of cold carcass $(\mathrm{P}=0.08)$ and picnic shoulder $(\mathrm{P}=0.09)$ did not differ among genetic groups (Table 3 ).

No changes were observed for any meat quality variables that were evaluated among genetic groups $(P>0.05)$, with the exception of drip loss $(P=0.01)$ which was greater in pork from Pietrain compared to Duroc and Piau crossbred gilts (Table 4).

The nutritional plans did not affect any of the meat quality variables that were evaluated $(P>0.05)$ with the exception of ether extract $(P=0.01)$, which was greater in gilts that were fed Low versus High nutritional plans (Table 4).

\section{Discussion}

\subsection{Barrows}

A lower final body weight was observed in Piau crossbred barrows as expected, as these have a greater fat deposition when compared to the other breeds that were evaluated. Moreover, the
Piau breed has a slow growth compared to Duroc and Pietrain pigs, which in turn were selected for their high growth rate as wells as their low feed conversion rate (Wood et al., 2004). Low feed conversion rates observed in Duroc and Pietrain crossbred pigs may be explained by high ADG values compared to Piau crossbred pigs, since the average daily intake was unaffected between genetic groups.

The nutritional plans did not affect any of the performance variables, only increased the digestible lysine daily intake, because pigs can tolerate a considerable excess of amino acids in the diets, including lysine, without changing the voluntary feed intake (Kerr et al., 2003).

In general, Duroc and Pietrain crossbred barrows had greater trimmed cut yields and lower values of RFT than Piau crossbred barrows. Such results may have occurred as a consequence of the intense selection process for lean growth and the decrease in fat that both Pietrain and Duroc have undergone (Cameron et al., 2000; Fabian et al., 2003).

Pigs that were fed Medium and High nutritional plans had greater LEA compared to those that were fed a Low nutritional plan, thereby confirming that the content of dietary digestible lysine directly affects protein deposition (Katsumata et al., 2018). It is worth noting that greater values of LEA were observed concomitantly with the improvement inthe feed conversion rate of barrows. This clearly demonstrates that the change in the composition of BW gain of barrows is due to a greater skeletal muscle deposition.

Differences observed in drip loss among genetic groups may be explained by the differences in muscle type fibers of the Longissimus muscle. According to Choe et al. (2008) and Li et al. (2016), the Longissimus muscle is mainly composed of type IIB fibers (glycolytic) and contains a low proportion of type I fibers (oxidative), thereby leading to a high concentration of lactate within the first hour postmortem. Additionally, the frequency of type I fibers is positively associated with the carcass $\mathrm{pH}$ at $45 \mathrm{~min}$ postmortem and negatively associated with drip loss (Kim et al., 2018). Thus, the Piau crossbred barrows probably had a high frequency of type I and low frequency of type II muscle fibers in the Longissimus muscle compared to the 
other genetic groups that were evaluated, since the frequency of glycolytic muscle fibers may vary among breeds (Chen et al., 2018). A greater frequency of type I and lower frequency of type II muscle fibers in the Longissimus muscle of a local pig breed (Pulawska) compared to commercial pig breeds (Wojtysiak \& Połtowicz, 2014) supports our hypothesis.

\subsection{Gilts}

Gilts were initially selected to have similar BWi among genetic groups and nutritional plans. However, BWi differed among genetic groups due to the discrepancy in their growth rate (Cameron et al., 1990), which in turn affected the growth rate curve and the BW at maturity (Fisher et al., 2003). Therefore, the BWf was certainly affected by the BWi of the gilts. Moreover, the discrepancy from each paternal breed that was used in the present study to compose the genetic groups affected the performance traits. Duroc pigs have a high BW gain as one of the main characteristics of the breed (Wood et al., 2004), while Pietrain pigs have a low feed intake (Bertol et al., 2013) compared to other genetically improved breeds, and the Piau breed is mainly characterized by its slow growth rate (Faria et al., 2009; Peixoto et al., 2009).

The low feed intake of Pietrain compared to Duroc crossbred gilts is due to the selection process for a low feed conversion rate and high lean growth that Pietrain has undergone, which has negatively impacted their voluntary intake (Bertol et al., 2013). Thus, it was expected that Duroc crossbred gilts pigs would present with a greater feed intake value since Duroc have been reported to have greater feed intakes compared to other breeds that were used in genetic improvement programs (Augspurger et al., 2002).

As no difference was observed for average daily intake of gilts, the increase in digestible lysine intake was due to the different contents of this amino acid in the nutritional plans that were evaluated.

The greater HCY of Duroc and Pietrain compared to Piau crossbred gilts was due to their greater slaughter weight and carcass composition, since a greater RFT and lower LEA were observed in carcasses of Piau compared to Duroc and Pietrain crossbred gilts. The amount of subcutaneous fat is negatively correlated with the amount of lean tissue (Suzuki et al., 2005), and consequently contributes to a decrease in the trimmed cuts yield. Thus, the greater LEA and trimmed cuts yield that were observed in Duroc and Pietrain crossbred gilts clearly demonstrates their greater ability for lean tissue deposition compared to Piau crossbred gilts (Edwards et al., 2003, 2006; Wood et al., 2004).

The drip loss from crossbred gilts was different among genetic groups, where meat from Duroc and Piau crossbred gilts had the smallest value of drip loss compared to the other genetic groups. This was likely due to differences in frequency of muscle fiber type among breeds, as previously discussed in barrows, since Pietrain crossbred gilts may have a higher frequency of glycolytic muscle.

The intramuscular fat that was measured by quantification of ether extract content of meat was higher with the decrease in lysine in nutritional plans, similar to others' observations
(Katsumata et al., 2018). Collectively, these results indicate that intramuscular fat content may change according to the variation in digestible lysine of nutritional plans when the dietary content of this amino acid is lower than the amount required by the animals.

It has been reported that pigs that are fed low contents of lysine have greater mRNA abundance of PPAR $\gamma$ and SREBP-1, thus showing greater lipogenesis in the skeletal muscle (Schadinger et al., 2005), which may have occurred in this particular experiment. Additionally, the free L-carnitine content was lower in the skeletal muscle of pigs that were fed low contents of digestible lysine (Katsumata et al., 2005). Thus, since L-carnitine plays a crucial role in lipid oxidation by transporting fatty acyl-CoA through the mitochondrial membrane, the low contents of digestible lysine may have decreased the lipid oxidation allowing the deposition of fatty acids in the skeletal muscle.

\section{Conclusions}

In the current study, Duroc and Pietrain crossbred barrows and gilts had greater performance and carcass yields compared to Piau crossbred pigs. There was no interaction between genetic group and nutritional plans for all traits, and few traits were affected by the nutritional plan. However, the genetic background of the pig during the growing-finishing phase seems to depend on the response to dietary lysine.

\section{Acknowledgements}

We would like to thank Fundação de Amparo à Pesquisa do Estado de Minas Gerais (FAPEMIG), Conselho nacional de Desenvolvimento Científico e Tecnológico (CNPq), Coordenação de Aperfeiçoamento de Pessoal de Nivel Superior (CAPES), and Instituto Nacional de Ciência e Tecnologia - Ciência Animal (INCT-CA).

\section{References}

American Meat Science Association - AMSA. (1995). Research guidelines for cookery, sensory evaluation and tenderness measurements of fresh meat. Chicago: National Livestock and Meat Board, IL.

American Oil Chemists' Society - AOCS. (2009). Official methods and recommended practices of the AOCS. Denver: AOCS.

Association of Official Analitical Chemists - AOAC. (1990). Official methods of analysis (15th ed.). Washington: AOAC.

Augspurger, N. R., Ellis, M., Hamilton, D. N., Wolter, B. F., Beverly, J. L., \& Wilson, E. R. (2002). The effect of sire line on the feeding patterns of grow-finish pigs. Applied Animal Behaviour Science, 75(2), 103-114. http://dx.doi.org/10.1016/S0168-1591(01)00188-5.

Bertol, T. M., de Campos, R. M., Ludke, J. V., Terra, N. N., Figueiredo, E. A., Coldebella, A., Santos, J. I. Fo., Kawski, V. L., \& Lehr, N. M. (2013). Effects of genotype and dietary oil supplementation on performance, carcass traits, pork quality and fatty acid composition of backfat and intramuscular fat. Meat Science, 93(3), 507-516. http://dx.doi.org/10.1016/j.meatsci.2012.11.012. PMid:23273458.

Brasil. Ministério da Agricultura, Pecuária e Abastecimento. (1997). Regulamento da Inspeção Industrial e Sanitária de Produtos de Origem Animal. Brasília: Ministério da Agricultura, Pecuária e Abastecimento.

Cameron, N. D., Enser, M., Nute, G. R., Whittington, F. M., Penman, J. C., Fisken, A. C., Perry, A. M., \& Wood, J. D. (2000). Genotype with 
nutrition interaction on fatty acid composition of intramuscular fat and the relationship with flavour of pig meat. Meat Science, 55(2), 187-195. http://dx.doi.org/10.1016/S0309-1740(99)00142-4. PMid:22061084.

Cameron, N. D., Warriss, P. D., Porter, S. J., \& Enser, M. B. (1990). Comparison of Duroc and British landrace pigs for meat a and eating quality. Meat Science, 27(3), 227-247. http://dx.doi.org/10.1016/03091740(90)90053-9. PMid:22055287.

Chen, B., Ao, Q., Chen, S., Wei, Y., Guo, Y., Lan, G., Jiang, Q., \& Jiang, H. (2018). Assessment of M. longissimus fibre types and metabolic enzymes in Bama miniature pigs and Landrace swine. Italian Journal of Animal Science, 17(1), 1-8. http://dx.doi.org/10.1080/182805 1X.2017.1326854.

Choe, J. H., Choi, Y. M., Lee, S. H., Shin, H. G., Ryu, Y. C., Hong, K. C., \& Kim, B. C. (2008). The relation between glycogen, lactate content and muscle fiber type composition, and their influence on postmortem glycolytic rate and pork quality. Meat Science, 80(2), 355-362. http:// dx.doi.org/10.1016/j.meatsci.2007.12.019. PMid:22063340.

Coble, K. F., Wu, F., DeRouchey, J. M., Tokach, M. D., Dritz, S. S., Goodband, R. D., Woodworth, J. C., \& Usry, J. L. (2018). Effect of standardized ileal digestible lysine and added copper on growth performance, carcass characteristics, and fat quality of finishing pigs. Journal of Animal Science, 96(8), sky184. http://dx.doi.org/10.1093/ jas/sky184. PMid:29762786.

D’Astous-Pagé, J., Gariépy, C., Blouin, R., Cliche, S., Méthot, S., Sullivan, B., Fortin, F., \& Palin, M.-F. (2017). Identification of single nucleotide polymorphisms in carnosine-related genes and effects of genotypes on pork meat quality attributes. Meat Science, 134, 54-60. http:// dx.doi.org/10.1016/j.meatsci.2017.07.019. PMid:28759885.

Edwards, D. B., Bates, R. O., \& Osburn, W. N. (2003). Evaluation of Duroc- vs. Pietrain-sired pigs for carcass and meat quality measures. Journal of Animal Science, 81(8), 1895-1899. http://dx.doi. org/10.2527/2003.8181895x. PMid:12926770.

Edwards, D. B., Tempelman, R. J., \& Bates, R. O. (2006). Evaluation of Duroc- vs. Pietrain-sired pigs for growth and composition. Journal of Animal Science, 84(2), 266-275. http://dx.doi.org/10.2527/2006.842266x. PMid:16424252.

Fabian, J., Chiba, L. I., Kuhlers, D. L., Frobish, L. T., Nadarajah, K., \& McElhenney, W. H. (2003). Growth performance, dry matter and nitrogen digestibilities, serum profile, and carcass and meat quality of pigs with distinct genotypes. Journal of Animal Science, 81(5), 11421149. http://dx.doi.org/10.2527/2003.8151142x. PMid:12772840.

Faria, D. A., Peixoto, J. O., Lopes, P. S., Paiva, S. R., Silva, P. V., \& Guimarães, S. E. F. (2009). Association between insulin-like growth factor I (IGF-I) microsatellite polymorphisms and important economic traits in pigs. Revista Brasileira de Zootecnia, 38(2), 265-270. http:// dx.doi.org/10.1590/S1516-35982009000200007.

Fisher, A. V., Green, D. M., Whittemore, C. T., Wood, J. D., \& Schofield, C. P. (2003). Growth of carcass components and its relation with conformation in pigs of three types. Meat Science, 65(1), 639-650. http://dx.doi.org/10.1016/S0309-1740(02)00266-8. PMid:22063259.

Honikel, K. O. (1985, November 21-22). How to measure the waterholding capacity of meat? recommendation of standardized methods. In P. V. Tarrant, G. Eikelenboom \& G. Monin (Eds.), Evaluation and control of meat quality in pigs: a Seminar in the CEC Agricultural Research Programme (pp. 129-142). Dordrecht: Springer Netherlands. http://dx.doi.org/10.1007/978-94-009-3301-9_11.

Hunterlab. (1996). Applications note: $C I E L^{*} a^{*} b^{*}$ color scale. Virginia: Hunterlab.
Katsumata, M., Kobayashi, H., Ashihara, A., \& Ishida, A. (2018). Effects of dietary lysine levels and lighting conditions on intramuscular fat accumulation in growing pigs. Animal Science Journal, 89(7), 1-6. http://dx.doi.org/10.1111/asj.13019. PMid:29707871.

Katsumata, M., Kobayashi, S.-i., Matsumoto, M., Tsuneishi, E., \& Kaji, Y. (2005). Reduced intake of dietary lysine promotes accumulation of intramuscular fat in the Longissimus dorsi muscles of finishing gilts. Animal Science Journal, 76(3), 237-244. http://dx.doi. org/10.1111/j.1740-0929.2005.00261.x.

Kerr, B. J., Southern, L. L., Bidner, T. D., Friesen, K. G., \& Easter, R. A. (2003). Influence of dietary protein level, amino acid supplementation, and dietary energy levels on growing-finishing pig performance and carcass composition. Journal of Animal Science, 81(12), 30753087. http://dx.doi.org/10.2527/2003.81123075x. PMid:14677864.

Kim, G.-D., Yang, H.-S., \& Jeong, J.-Y. (2018). Intramuscular variations of proteome and muscle fiber type distribution in semimembranosus and semitendinosus muscles associated with pork quality. Food Chemistry, 244, 143-152. http://dx.doi.org/10.1016/j.foodchem.2017.10.046. PMid:29120762.

Li, Y., Li, F., Wu, L., Wei, H., Liu, Y., Li, T., Tan, B., Kong, X., Yao, K., Chen, S., Wu, F., Duan, Y., \& Yin, Y. (2016). Effects of dietary protein restriction on muscle fiber characteristics and mTORC1 pathway in the skeletal muscle of growing-finishing pigs. Journal of Animal Science and Biotechnology, 7(1), 47. http://dx.doi.org/10.1186/ s40104-016-0106-8. PMid:27555912.

Liu, Y., Yang, X., Jing, X., He, X., Wang, L., Liu, Y., \& Liu, D. (2018). Transcriptomics Analysis on Excellent Meat Quality Traits of Skeletal Muscles of the Chinese Indigenous Min Pig Compared with the Large White Breed. International Journal of Molecular Sciences, 19(1), 21. http://dx.doi.org/10.3390/ijms19010021. PMid:29271915.

Peixoto, J. O., Faria, D. A., Silva, P. V., Fonseca, I., Lopes, P. S., \& Guimarães, S. E. F. (2009). Association between leptin gene single nucleotide polymorphisms and carcass traits in pigs. Revista Brasileira de Zootecnia, 38(2), 271-276. http://dx.doi.org/10.1590/ S1516-35982009000200008.

Rostagno, H. S., Albino, L. F. T., Donzele, J. L., Gomes, P. C., Oliveira, R. F. M., Lopes, D. C., Ferreira, A. S., Barreto, S. L. T., \& Euclydes, R. F. (2011). Brazilian Tables for Poultry and Swine: Composition of Feedstuffs and Nutritional Requirements (3rd ed). Viçosa: Universidade Federal de Viçosa.

Schadinger, S. E., Bucher, N. L. R., Schreiber, B. M., \& Farmer, S. R. (2005). PPAR $\gamma 2$ regulates lipogenesis and lipid accumulation in steatotic hepatocytes. American Journal of Physiology. Endocrinology and Metabolism, 288(6), E1195-E1205. http://dx.doi.org/10.1152/ ajpendo.00513.2004. PMid:15644454.

Serão, N. V. L., Veroneze, R., Ribeiro, A. M. F., Verardo, L. L., Braccini, J. No., Gasparino, E., Campos, C. F., Lopes, P. S., \& Guimarães, S. E. F. (2011). Candidate gene expression and intramuscular fat content in pigs. Journal of Animal Breeding and Genetics, 128(1), 28-34. http:// dx.doi.org/10.1111/j.1439-0388.2010.00887.x. PMid:21214641.

Suzuki, K., Irie, M., Kadowaki, H., Shibata, T., Kumagai, M., \& Nishida, A. (2005). Genetic parameter estimates of meat quality traits in Duroc pigs selected for average daily gain, longissimus muscle area, backfat thickness, and intramuscular fat content. Journal of Animal Science, 83(9), 2058-2065. http://dx.doi.org/10.2527/2005.8392058x. PMid:16100060.

Veroneze, R., Lopes, P. S., Guimarães, S. E. F., Guimarães, J. D., Costa, E. V., Faria, V. R., \& Costa, K. A. (2014). Using pedigree analysis to monitor the local Piau pig breed conservation program. Archivos 
de Zootecnia, 63(241), 45-54. http://dx.doi.org/10.4321/S000405922014000100005.

Wojtysiak, D., \& Połtowicz, K. (2014). Carcass quality, physico-chemical parameters, muscle fibre traits and myosin heavy chain composition of m. longissimus lumborum from Puławska and Polish Large White pigs. Meat Science, 97(4), 395-403. http://dx.doi.org/10.1016/j. meatsci.2014.03.006. PMid:24769095.

Wood, J. D., Nute, G. R., Richardson, R. I., Whittington, F. M., Southwood, O., Plastow, G., Mansbridge, R., Costa, N., \& Chang, K. C. (2004).
Effects of breed, diet and muscle on fat deposition and eating quality in pigs. Meat Science, 67(4), 651-667. http://dx.doi.org/10.1016/j. meatsci.2004.01.007. PMid:22061815.

Zou, C., Li, S., Deng, L., Guan, Y., Chen, D., Yuan, X., Xia, T., He, X., Shan, Y., \& Li, C. (2017). transcriptome analysis reveals long intergenic noncoding RNAs contributed to growth and meat quality differences between Yorkshire and Wannanhua Pig. Genes, 8(8), 203. http://dx.doi.org/10.3390/genes8080203. PMid:28820450. 